\title{
Biosynthesis of acetylacetone inspired by its biodegradation
}

\author{
Yifei Zhou ${ }^{1,2}$, Yamei Ding ${ }^{3}$, Wenjie Gao ${ }^{1}$, Jichao Wang ${ }^{1}$, Xiutao Liu ${ }^{1,2}$, Mo Xian ${ }^{1}$, Xinjun Feng ${ }^{1 *}$ [D \\ and Guang Zhao ${ }^{1,4^{*}}$
}

\begin{abstract}
Background: Acetylacetone is a commercially bulk chemical with diverse applications. However, the traditional manufacturing methods suffer from many drawbacks such as multiple steps, harsh conditions, low yield, and environmental problems, which hamper further applications of petrochemical-based acetylacetone. Compared to conventional chemical methods, biosynthetic methods possess advantages such as being eco-friendly, and having mild conditions, high selectivity and low potential costs. It is urgent to develop biosynthetic route for acetylacetone to avoid the present problems.

Results: The biosynthetic pathway of acetylacetone was constructed by reversing its biodegradation route, and the acetylacetone was successfully produced by engineered Escherichia coli (E. coli) by overexpression of acetylacetone-cleaving enzyme (Dke1) from Acinetobacter johnsonii. Several promising amino acid residues were selected for enzyme improvement based on sequence alignment and structure analysis, and the acetylacetone production was improved by site-directed mutagenesis of Dke1. The double-mutant (K15Q/A60D) strain presented the highest acetylacetone-producing capacity which is 3.6-fold higher than that of the wild-type protein. Finally, the strain accumulated $556.3 \pm 15.2 \mathrm{mg} / \mathrm{L}$ acetylacetone in fed-batch fermentation under anaerobic conditions.
\end{abstract}

Conclusions: This study presents the first intuitive biosynthetic pathway for acetylacetone inspired by its biodegradation, and shows the potential for large-scale production.

Keywords: Acetylacetone biosynthesis, Acetylacetone-cleaving enzyme, Rational design, Site-directed mutagenesis, $\beta$-Dicarbonyl compounds

\section{Background}

Acetylacetone, also known as 2,4-pentanedione (CAS No. 123-54-6), is an important commodity chemical and widely used as a fuel additive, as dyeing intermediate, in the fields of metal extraction, metal plating, and resin modification [1]. Traditionally, acetylacetone is manufactured through chemical routes using acetone and ketene, which is produced by pyrolysis of acetone or acetic acid at a temperature of $700-800{ }^{\circ} \mathrm{C}$, with carbon monoxide,

\footnotetext{
*Correspondence: fengxj@qibebt.ac.cn; zhaoguang@qibebt.ac.cn

${ }^{1}$ CAS Key Laboratory of Biobased Materials, Qingdao Institute

of Bioenergy and Bioprocess Technology, Chinese Academy of Sciences, Qingdao 266101, China

Full list of author information is available at the end of the article
}

methane, hydrogen formed as by-products [2, 3]. In specific, esterification of ketene and acetone forms isopropenyl acetate (IPA), in the presence of a strong acid catalyst. Then, IPA is transformed into acetylacetone at $500-600{ }^{\circ} \mathrm{C}$ with metallic molybdenum as a catalyst, whereby the yield is only about $45 \%$. In conclusion, the chemical routes suffer from drawbacks such as multiple steps, harsh conditions, low yield, and environmental problems, which hamper further applications of petrochemical-based acetylacetone. To address the issue, new methods need to be developed for acetylacetone preparation. Compared to conventional chemical methods, biosynthetic methods are expected to have advantages such as being eco-friendly and having mild conditions, high

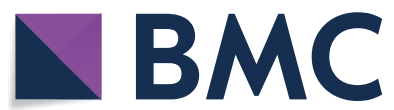

(c) The Author(s) 2020. This article is licensed under a Creative Commons Attribution 4.0 International License, which permits use, sharing, adaptation, distribution and reproduction in any medium or format, as long as you give appropriate credit to the original author(s) and the source, provide a link to the Creative Commons licence, and indicate if changes were made. The images or other third party material in this article are included in the article's Creative Commons licence, unless indicated otherwise in a credit line to the material. If material is not included in the article's Creative Commons licence and your intended use is not permitted by statutory regulation or exceeds the permitted use, you will need to obtain permission directly from the copyright holder. To view a copy of this licence, visit http://creativeco mmons.org/licenses/by/4.0/. The Creative Commons Public Domain Dedication waiver (http://creativecommons.org/publicdomain/ zero/1.0/) applies to the data made available in this article, unless otherwise stated in a credit line to the data. 
selectivity and low potential costs [4], and have been used to produce numerous products, e.g., bio-based chemicals [5], pharmaceuticals [6], biopolymers [7]. For acetylacetone, the theoretical yield is as high as $1.5 \mathrm{~mol} / \mathrm{mol} \mathrm{glu}$ cose by bioconversion. Predictably, low cost will also be obtained thanks to the cheap carbon source and the high yield.

Limited studies indicate that acetylacetone is biodegradable [8]. A strain of Acinetobacter johnsonii was isolated and proved to have the ability to utilize acetylacetone as a sole carbon source. To reveal the decomposition mechanism, a novel $\mathrm{C}-\mathrm{C}$ bond-cleaving enzyme, acetylacetone-cleaving enzyme (Dke1, EC 1.13.11.50), was found and purified from A. johnsonii [9]. The Dke1 enzyme can activate oxygen to cleave acetylacetone into acetate and methylglyoxal, followed by the conversion of methylglyoxal into lactate by glyoxalase. However, the natural biosynthesis of acetylacetone has not yet been reported. In previous studies, some non-natural products had been bio-synthesized by reversing their biodegradation pathway. An artificial biosynthetic pathway to methylacetoin was constructed by redirecting the methylacetoin biodegradation, and the titer achieved at $3.4 \mathrm{~g} / \mathrm{L}$ by enzyme screening and metabolic engineering [4]. The direct biocatalytic route of 1,4-butanediol mirroring its biodegradation pathway was reported with a production of $18 \mathrm{~g} / \mathrm{L}$ [10]. In addition, the engineered reversal of the $\beta$-oxidation cycle was adopted for fatty-acid-derived compounds' biosynthesis, and a series of short-, medium-, and long-chain products were obtained at high yields [11-13]. These successful cases provided a possible strategy to our research for acetylacetone biosynthesis.

In this work, we established for the first time the biosynthetic pathway of acetylacetone from fermentable sugars (Fig. 1) inspired by the known acetylacetone biodegradation pathway. It was proved that the acetylacetone decomposition process catalyzed by Dke1 was reversible. The Dke1 activity was improved by rational design, resulting in enhanced acetylacetone production under shake-flask conditions, and the underlying mechanism was proposed. Fed-batch fermentation was conducted to evaluate the potential for large-scale production.

\section{Results and discussion}

Design and verification of the acetylacetone biosynthesis pathway

Acetylacetone is not a naturally occurring metabolite; however, it can be catabolized by Acinetobacter johnsonii as a carbon source [8]. As reported, one molecule of acetylacetone degrades into one acetate and one methylglyoxal catalyzed by acetylacetone-cleaving enzyme Dke1. Methylglyoxal can be produced marginally through glycolysis [14], and acetate is a major product during sugar fermentation especially under anaerobic conditions. Thus, we proposed to achieve acetylacetone production from methylglyoxal and acetate by redirecting the reaction. As shown in Fig. 1, glyceraldehyde 3-phosphate from glycolysis pathway was converted into glycerone phosphate and methylglyoxal by the action of triosephosphate isomerase (TpiA) and methylglyoxal synthase (MgsA), respectively. Acetyl-CoA was converted into acetate by acetate kinase. Methylglyoxal and acetate were finally transformed into acetylacetone by Dke1.

To test the hypothetical acetylacetone biosynthetic pathway, acetylacetone-cleaving enzyme (Dke1) from A. johnsonii (accession No. Q8GNT2.1) was cloned into plasmid pETDuet-1, and then the recombinant plasmid was introduced into E. coli BL21 (DE3) to construct an acetylacetone producing strain. The expression of the Dke1 was first checked by SDS-PAGE, and the corresponding bands with molecular weights of $17 \mathrm{kDa}$ were observed clearly (Additional file 1: Fig. S1). The resulting

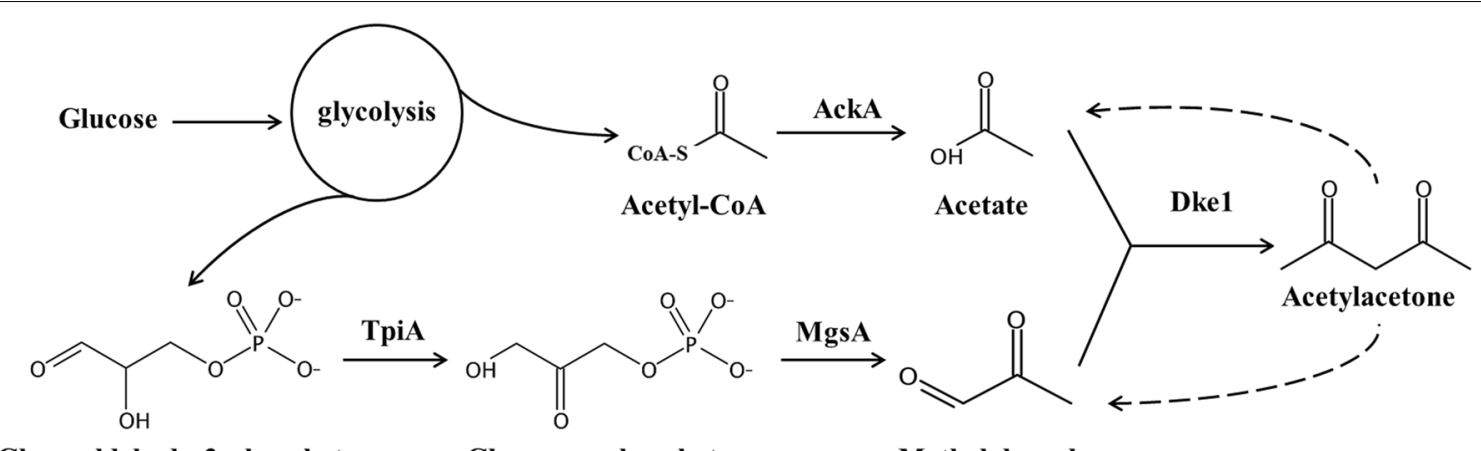

Glyceraldehyde 3-phosphate

Glycerone phosphate

Methylglyoxal

Fig. 1 Biodegradation-inspired biosynthetic pathway of acetylacetone. Acetylacetone biodegradation is presented with a dashed line, and the constructed biosynthetic pathways are presented using a solid line. The enzymes used are as follows: AckA, acetate kinase; TpiA, triose-phosphate isomerase; MgsA, methylglyoxal synthase; Dke1, acetylacetone-cleaving enzyme 
strain Q3030 was cultured under shake-flask conditions, and the fermentation products were analyzed by GCMS. However, no acetylacetone was detected. We then referred back to the acetylacetone biodegradation pathway. As the biodegradation of acetylacetone was activated by oxygen, we speculated the biosynthesis direction was suppressed under aerobic conditions. Thus, anaerobic cultivation in a sealed serum bottle with nitrogen was carried out for further verification. This time, the production of acetylacetone was confirmed by GC-MS analysis. As shown in Fig. 2, a specific peak with a mass of $100 \mathrm{Da}$ was detected, and dissociation of this ion led to other masses such as 43 and $85 \mathrm{Da}$, exactly the same with acetylacetone standard. Under this condition, the concentration of acetylacetone in fermentation broth was $32.6 \pm 1.0 \mathrm{mg} / \mathrm{L}$. Furthermore, the production of acetylacetone was also performed in vitro in Tris buffer $(\mathrm{pH}$ 7.5) containing purified Dke1 protein, methylglyoxal and ammonium acetate at $37^{\circ} \mathrm{C}$, and $129.5 \pm 8.9 \mathrm{mg} / \mathrm{L}$ acetylacetone was accumulated in $24 \mathrm{~h}$. Compared with in vivo system, higher product titer was achieved with in vitro system, probably owing to a relatively simple pathway without side reactions [15].

A sufficient supply of precursors is necessary for the efficient synthesis of the final products [16]. As one of the main metabolites in E. coli under anaerobic condition, acetate should be sufficient for acetylacetone biosynthesis. But in general, methylglyoxal synthesis is inhibited in cell $[14,17]$. So the methylglyoxal content in the flask was improved by extra supplement with a concentration of $0.1 \mathrm{mM}$ or overexpression of the key genes (tpiA and $m g s A$ ) for enhanced acetylacetone production (Fig. 1). However, no more acetylacetone was accumulated. Meanwhile, the in vitro experiment with $20 \mathrm{mM}$ methylglyoxal was conducted, and the production of acetylacetone $(128.9 \pm 8.6 \mathrm{mg} / \mathrm{L})$ did not show significant difference with that with $10 \mathrm{mM}$ methylglyoxal $(p=0.94)$. So, we speculated that low activity of Dke1 might be the primary reason of low acetylacetone yield. Then, the acetylacetone-cleaving enzyme was first screened. Two more genes encoding acetylacetone-cleaving enzyme from Paraburkholderia xenovorans LB400 (P_Dke1, accession No. NC_007951.1) and Tistrella mobilis (T_Dke1, accession No. NC_017966.1) were cloned and used for acetylacetone production. Unfortunately, no acetylacetone was detected using engineered strains with P_Dke1 or T_Dke1. So, other strategies should be considered for higher acetylacetone production.

\section{Rational design of Dke1}

Protein engineering using directed evolution or rational design has been developed rapidly, and has acted as a powerful tool for enzyme improvement $[18,19]$. Especially, protein sequence information combined with computational modeling tools can be used to identify promising amino acid sites and can be selected for enzyme engineering [20]. Thus, rational design strategies were considered for increasing Dke1 activity.

To improve the Dke1 catalytic activity, multiple amino acid sequence alignment was performed between Dke1 and 27 other acetylacetone-cleaving enzymes or hypothetical proteins sharing more than $60 \%$ identity with Dke1 (Additional file 2: Table S1). Among 153 amino acid residues in Dke1, 52 residues were conserved in all 28 proteins, and referred to as definitely conserved sites (highlighted in red in Fig. 3); 44 amino acid residues appeared in more than 14 other proteins, and defined as relatively conserved sites (highlighted in yellow in Fig. 3); a

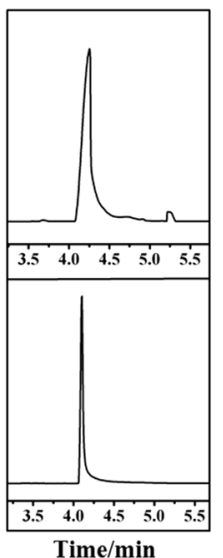

b

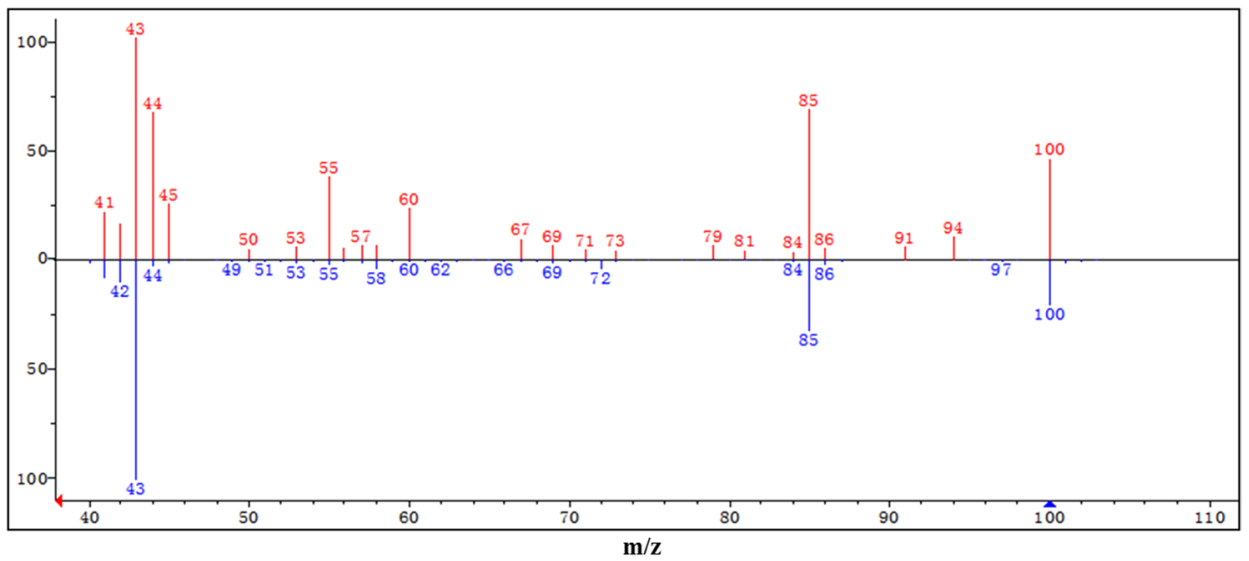

Fig. 2 Verification of the production of acetylacetone by engineered E. coli strain using GC-MS. GC chromatography (a) and mass spectrometry (b) results are shown for acetylacetone standard (lower panel) and Q3030 culture (upper panel) 


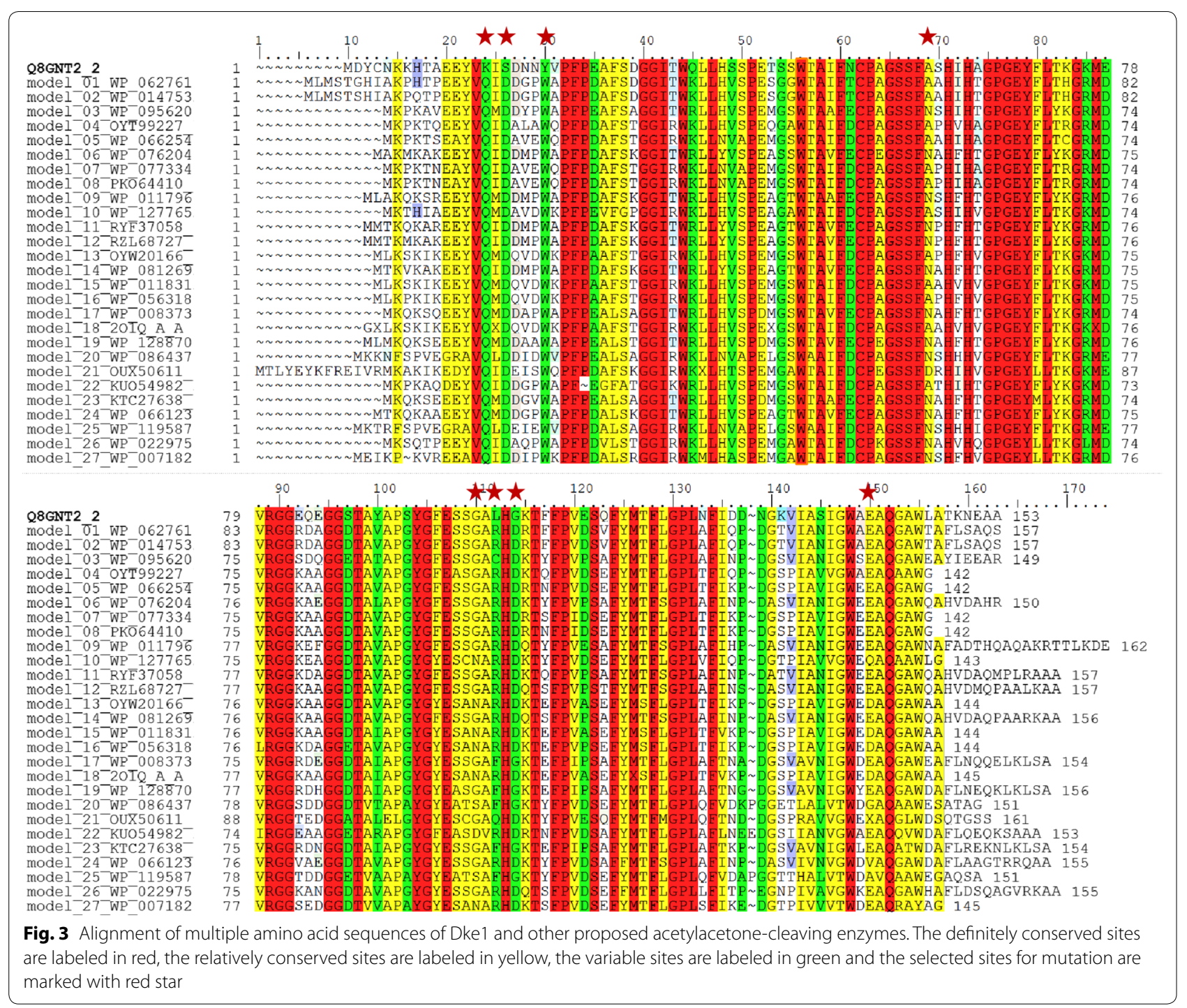

and 19 amino acid residues rarely (less than 26\%) showed up in other proteins, and were called variable sites (highlighted in green in Fig. 3). Among the variation sites, three amino acid residues were found conserved in all proteins except Dke1, and site-directed mutagenesis was performed to construct Dke1 single mutants harboring each substitution as its homologs. Then, shake flask cultivation was performed to test the effect of each mutation. The strain with Dke1 K15Q (Q3080) accumulated $60.6 \pm 0.7 \mathrm{mg} / \mathrm{L}$ acetylacetone, which is 1.9 -fold higher than that of the wild-type strain Q3030 ( $p<0.01)$ (Fig. 4). However, the strain with Dke1 Y21W (Q3082) only produced $28.8 \pm 1.0 \mathrm{mg} / \mathrm{L}$ acetylacetone, and the production reduced dramatically to $7.0 \pm 0.4 \mathrm{mg} / \mathrm{L}$ when Dke1 S17D was used in strain Q3081.

Meanwhile, 3D structure analysis of the wild-type Dke1 was performed based on its crystal structure (PDB
ID: 3BAL). In the crystal structure of the ligand-free Dke1, the $\mathrm{Fe}^{2+}$-coordinating His-62, His-64 and His104 comprise the substrate catalytic center [21]. The definitely conserved sites occupy about three quarters of the substrate channel, which are the most important amino acid residues for maintaining structure and function of the proteins (Additional file 1: Fig. S2). These sites would not be modified in this study. Most of the relatively conserved sites cover about one quarter of the substrate channel, while a few sites are located close to the catalytic center. We analyzed the possible impact from the mutation of the relatively conserved sites near the catalytic center and all the variation sites. By analysis of the key influence factors including properties of amino acids, hydrogen bonding, electron distribution, and charge properties, 5 sites were selected as potential mutation sites for improving Dke1 activity (Table 1). For 


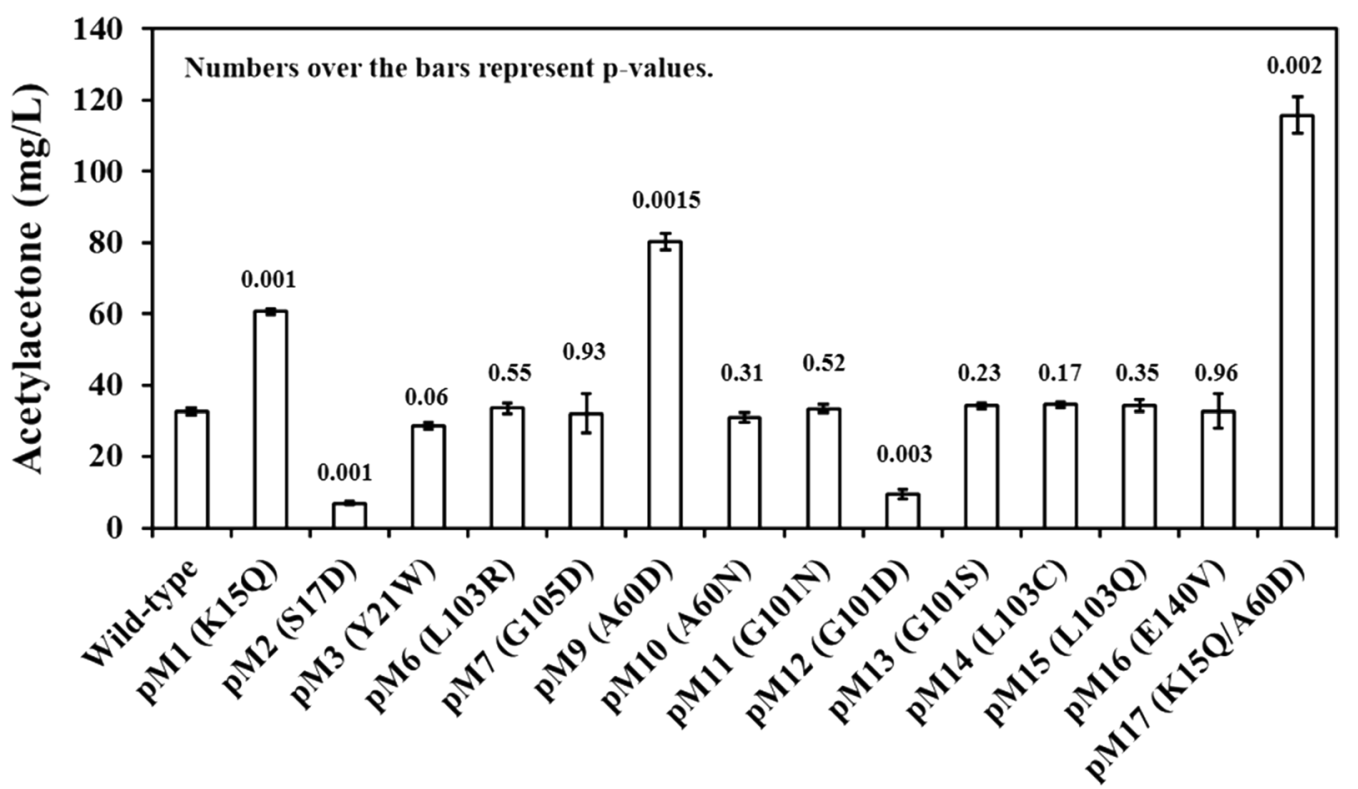

Fig. 4 Effect of Dke1 mutagenesis on acetylacetone production in flask cultivation. Data were obtained after each strain was induced for $24 \mathrm{~h}$ in liquid LB medium. All the experiments were carried out in triplicate. All $p$ values are based on two-tailed tests (wild type and mutant strain) and presented over the bars

Table 1 Analysis of the proposed sites for site-directed mutagenesis

\begin{tabular}{|c|c|c|}
\hline Proposed sites & Mutation information & Annotation \\
\hline A60 & N60 or D60 & $\begin{array}{l}\text { The carbonyl oxygen of A60 (Additional file 1: Fig. S3b) is hydrogen bonded to H62. The electrons could be } \\
\text { transferred to H62 after Ala mutated to Asp or Asn }\end{array}$ \\
\hline G101 & N101, D101 or S101 & $\begin{array}{l}\text { The } \mathrm{N} \text { of the main chain of G101 (Additional file 1: Fig. S3c) is hydrogen bonded to the O of the main chain } \\
\text { of H64. When Gly was mutated to Asp, Asn or Ser, the electron distribution of site } 101 \text { will change and } \\
\text { thus affect the catalytic activity }\end{array}$ \\
\hline L103 & R103, Q103 or C103 & $\begin{array}{l}\text { L103 (Additional file 1: Fig. S3c) was located close to H104; the property of site } 103 \text { directly affects } \mathrm{H} 104 \text {. } \\
\text { When the nonpolar amino acid (Leu) was mutated to polar amino acid (GIn, Cys) or alkaline amino acid } \\
\text { (Arg), the influence to H104 from site } 103 \text { may change and thus affect the catalytic activity }\end{array}$ \\
\hline G105 & D105 & $\begin{array}{l}\text { When G105 (Additional file 1: Fig. S3c) was mutated to D105, the electronegativity of the catalytic activity } \\
\text { center will be significantly increased }\end{array}$ \\
\hline E140 & V140 & $\begin{array}{l}\text { E140 (Additional file 1: Fig. S3d) with hydrophobic amino acids around was located on the outer edge of the } \\
\text { hydrophobic channel. When the acidic amino acid (Glu) was mutated to a hydrophobic amino acid (Val), it } \\
\text { might be more conducive to discharge the catalytic product }\end{array}$ \\
\hline
\end{tabular}

example, the carbonyl oxygen of A60 was interacted with H62 by forming a hydrogen bond [22], and it will transfer electrons to H62 after mutated to D60 or N60 which might be helpful to enhance the catalytic activity. Then, 10 mutants were constructed and compared with Dke1 wild-type protein. As shown in Fig. 4, the strain with Dke1 A60D (Q3148) produced 80.2 $\pm 2.4 \mathrm{mg} / \mathrm{L}$ acetylacetone which is 2.5 -fold higher than that of the strain Q3030 ( $p<0.01)$. The strain with Dke1 G101D (Q3151) only produced $9.5 \pm 1.4 \mathrm{mg} / \mathrm{L}$ acetylacetone while the ability of other mutants was basically the same with wildtype Dke1 protein $(p>0.1)$.
As the mutations $\mathrm{K} 15 \mathrm{Q}$ and $\mathrm{A} 60 \mathrm{D}$ had shown improvement in acetylacetone production, the influence of the double mutant on acetylacetone production was also assessed. As Fig. 4 demonstrated, the strain carrying Dke1 K15Q/A60D (Q3170) exhibited the highest acetylacetone synthesis efficiency, and $115.7 \pm 5.1 \mathrm{mg} / \mathrm{L}$ acetylacetone was accumulated in the culture, which was 3.6-fold higher than that of strain Q3030 $(p<0.01)$. Dke1 activity was assayed in vitro using purified proteins and the activity of each enzyme showed a similar trend with acetylacetone production (Table 2). 
Table 2 Activity of the Dke1 and its mutants $(p<0.01$ compared with the wild type)

\begin{tabular}{ll}
\hline Enzyme & $\begin{array}{l}\text { Specific activity } \\
(\mu \mathrm{mol} / \mathrm{min} / \mathrm{mg} \\
\text { protein) }\end{array}$ \\
\hline WT & $0.8 \pm 0.01 \times 10^{-3}$ \\
K15Q & $1.7 \pm 0.07 \times 10^{-3}$ \\
A60D & $2.5 \pm 0.02 \times 10^{-3}$ \\
K15Q/A60D & $3.0 \pm 0.07 \times 10^{-3}$ \\
\hline
\end{tabular}

\section{Structural simulation and molecular docking of Dke1}

To reveal the molecular basis for increased enzymatic activity of Dke1 (K15Q/A60D), in silico structural modeling and molecular docking were performed using the $3 \mathrm{D}$ structure of Dke1 (PDB ID: 3BAL) as a model template. As shown in Fig. 5, no remarkable differences in the overall structure have been observed between wild-type and mutated Dke1 protein, implying that the variant is correctly folded. Interestingly, with the mutation of $\mathrm{K} 15 \mathrm{Q}$, the channel, through which substrates enter the enzyme reactive center, was widened. Furthermore, a neutral residue glutamine is less attractive to negative-charged acetate than lysine which is positive charged. Taken together both factors make it easier for acetate to arrive at the reactive site of Dke1. The residue A60, as a hydrophobic amino acid, is located close to the reactive center and its side chain is oriented toward the interior of the protein. The substitution of alanine by a hydrophilic residue, aspartate, changed the orientation of the side chain at position 60 , resulting in a reactive center with increased volume, which may be more conducive for substrate binding. In summary, these changes brought about by the double mutant increased substrate access to the enzyme active site, resulting in enhanced enzyme activity.

\section{Fed-batch fermentation}

As the strain Q3170 presented the highest acetylacetone production in flask cultivation, fed-batch fermentation was conducted in a 5-L bioreactor. The concentrated glucose was used for cell growth and controlled between 10 and $20 \mathrm{~g} / \mathrm{L}$ during fermentation. $0.2 \mathrm{mM}$ IPTG was added to induce the recombinant proteins when the cell density reached to about $30 \mathrm{OD}_{600}$ at $12 \mathrm{~h}$. Simultaneously, the sterilized air was switched to high-purity nitrogen for anaerobic environments. Cell growth, residual glucose and acetylacetone accumulation were monitored over the course of the fermentation. As shown in Fig. 6, the cell mass reached to a maximum $16.8 \mathrm{~g} \mathrm{DCW} / \mathrm{L}$ at $28 \mathrm{~h}$ and decreased slightly after $36 \mathrm{~h}$. A small amount of acetylacetone had already been synthesized before induction possibly due to Dke1 basal expression. After induction, acetylacetone rapidly accumulated and reached the

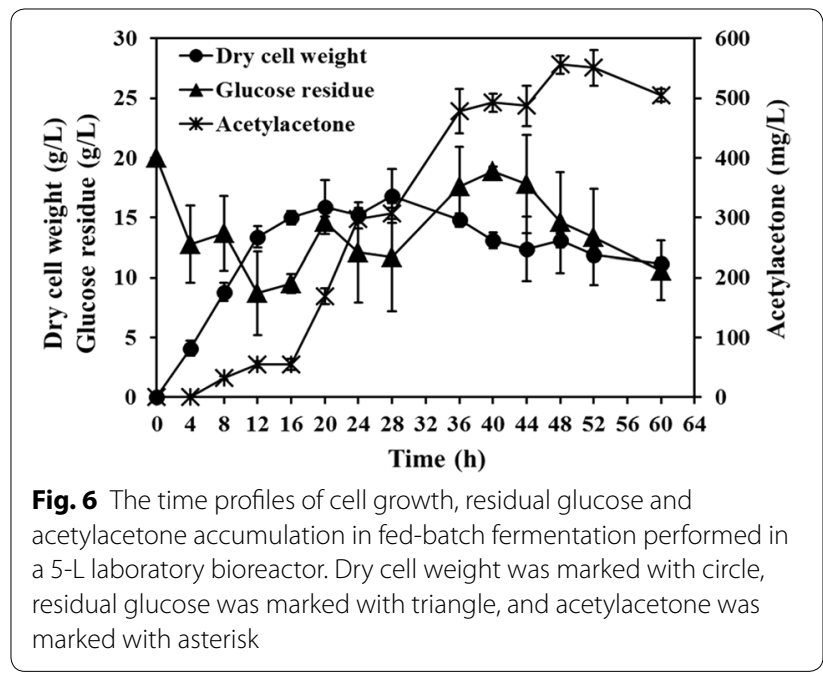

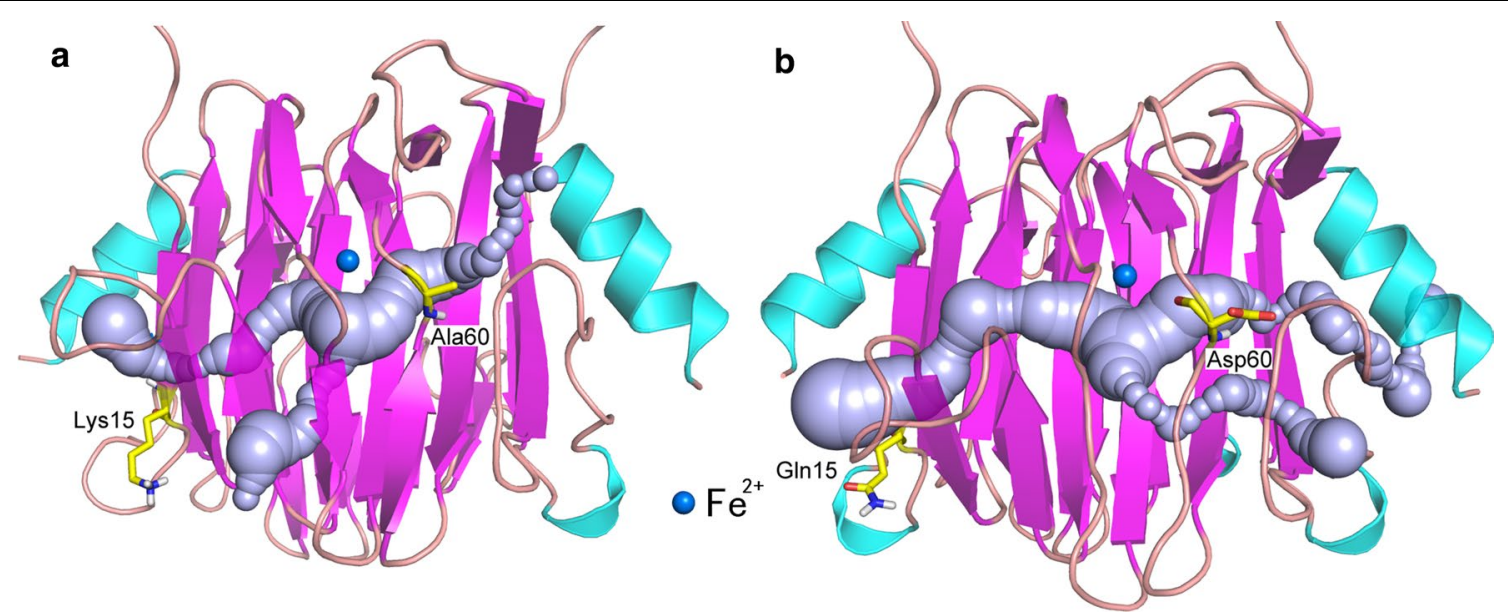

Fig. 5 Analysis of the Dke1 structure with molecular docking. a Wild-type. b K15Q/A60D mutant. The $\beta$-pleated sheet shown in purple, the a-helix shown in light blue, and the substrate channel shown in grey 
maximum of $556.3 \pm 15.2 \mathrm{mg} / \mathrm{L}$ at $48 \mathrm{~h}$ with a yield of $5.1 \mathrm{mmol} / \mathrm{mol}$ glucose. The productivity of $21.2 \mathrm{mg} / \mathrm{L} / \mathrm{h}$ was achieved during 16-36 h while only $1.1 \mathrm{mg} / \mathrm{L} / \mathrm{h}$ during the latter $24 \mathrm{~h}$.

Although the yield of acetylacetone from recombinant $E$. coli in this study was still relatively low, E. coli is a competitive species for industrial applications with short multiplication time, growth with inexpensive carbon sources and amenability to genetic modification [23]. Many strategies can be used for improving the acetylacetone yield in future study, such as metabolic flow regulation [24] and key genes expression level modulation [25]. Previous study has shown that acetylacetone has toxic side effects on the immune system of mammals [26], various aquatic organisms [27] and microorganisms [28]. The toxicity threshold of acetylacetone is $67 \mathrm{mg} / \mathrm{L}$ for Pseudomonas putida [28], and an excess of acetylacetone $(>1.5 \mathrm{~g} / \mathrm{L})$ can completely inhibit the cell growth of $A$. johnsonii [9]. We speculated that the acetylacetone toxicity might be one of the main reasons for the low yield. The toxicity of acetylacetone to E. coli cells was tested (Additional file 1: Fig. S4). The results showed that $100 \mathrm{mg} / \mathrm{L}$ acetylacetone has obvious inhibition effect on the growth of $E$. coli, and the cell was almost completely inhibited at a concentration of $5 \mathrm{~g} / \mathrm{L}$. The mechanism of toxicity, however, has still not been revealed. Further research is needed on the underlying mechanism to guide the metabolic engineering for higher production. Adaptive evolution is also an effective measure to improve the bacterial tolerance and enhance the production [29]. As E. coli naturally produces a mixture of ethanol, hydrogen, organic acids, such as lactic acid, succinic acid, acetic acid under anaerobic conditions [30], metabolic flow analysis and regulation are necessary to conduct for acetylacetone production enhancement. In addition, as the cultivation conditions play an important role on cell growth, product synthesis, and conversion efficiency, it is also worthy to optimize the medium components, substrate addition strategy, fermentation mode, etc. in future research.

\section{Conclusions}

The biosynthetic pathway of acetylacetone was constructed, and the acetylacetone was produced successfully from glucose by engineered $E$. coli by overexpression of acetylacetone-cleaving enzyme (Dke1). The production was improved by site-directed mutagenesis of Dke1 and the double mutant (K15Q/A60D) enabled the highest acetylacetone-producing capacity. Finally, $556.3 \pm 15.2 \mathrm{mg} / \mathrm{L}$ acetylacetone was obtained at $36 \mathrm{~h}$ post-induction in fed-batch fermentation under anaerobic condition. This study presents the first intuitive biosynthetic pathway of acetylacetone inspired by its biodegradation, and shows its potential for large-scale production. As reported, Dke1 is not absolutely specific for acetylacetone. Many related $\beta$-dicarbonyl compounds such as 3,5-heptanedione, 2,4-octanedione, 2-acetylcyclohexanone, ethylacetoacetate, etc. can be accepted as substrate by Dke1 $[8,9]$. As a consequence, the results of this study also provide a possible biosynthesis method for other $\beta$-dicarbonyl compounds.

\section{Materials and methods}

\section{Strains and plasmids}

All strains and plasmids used in this study are listed in Table 3. The primers used for plasmid construction and allele verification are listed in Additional file 2: Table S2. E. coli $\mathrm{DH} 5 \alpha$ (Invitrogen) was used for plasmids' preparation and BL21 (DE3) was used for recombinant protein expression and acetylacetone production. The genes encoding acetylacetone-cleaving enzyme from $A$. johnsonii, Paraburkholderia xenovorans LB400, and Tistrella mobilis were codon optimized and chemically synthesized by Beijing Liuhe BGI, and cloned into pETDuet-1 between EcoRI and BamHI sites to construct plasmids pETDuet-Dke1, pETDuet-P_Dke1, and pETDuet-T_ Dke1, respectively. Mutations were introduced into the Dke1 gene in pETDuet-Dke1 using an overlap extension PCR method [31]. The resulting plasmids were named pM1 to pM19, respectively. All the recombinant plasmids were verified by colony PCR and nucleotide sequencing.

\section{Protein expression and gel electrophoresis analysis}

To check the expression of the recombinant proteins, single colonies of E. coli BL21 (DE3) harboring different recombinant plasmids were cultured in LB medium containing appropriate antibiotics at $37^{\circ} \mathrm{C}$ overnight and then diluted 1:100 into fresh LB medium and induced with $0.2 \mathrm{mM}$ isopropyl- $\beta$-D-thiogalactopyranoside (IPTG) at an $\mathrm{OD}_{600}$ of $0.6-0.8$. The cells were collected from $10 \mathrm{~mL}$ bacteria cultures $4 \mathrm{~h}$ post-induction and washed with phosphate buffer ( $\mathrm{pH}$ 6.8). The washed cells were suspended in $1 \mathrm{~mL}$ buffer and subjected to ultrasonication (SCIENTZ JY92-IIN, $300 \mathrm{~W}, 3$ s pulse on and $3 \mathrm{~s}$ pulse off for $5 \mathrm{~min}$ ). The cell lysates were centrifuged and the protein expression was analyzed by SDS-PAGE.

\section{Dke1 activity assay}

The in vitro reaction system $(1 \mathrm{~mL})$ for the activity assay of Dke1 contained $0.1 \mu \mathrm{M}$ purified enzyme, $0.5 \mathrm{mM}$ $\mathrm{FeSO}_{4} \cdot 7 \mathrm{H}_{2} \mathrm{O}, 10 \mathrm{mM} \mathrm{MgCl} \cdot 6 \mathrm{H}_{2} \mathrm{O}, 10 \mathrm{mM} \mathrm{KCl}, 1 \mathrm{mM}$ DTT, $10 \mathrm{mM}$ methylglyoxal and $10 \mathrm{mM}$ ammonium acetate in $20 \mathrm{mM}$ Tris/ $\mathrm{HCl}$ buffer $(\mathrm{pH} 7.5)$ and was incubated at $37^{\circ} \mathrm{C}$ for $24 \mathrm{~h}$. The reaction mixture was centrifuged at $5000 \times g$ for $5 \mathrm{~min}$, and then the supernatant was subjected to HPLC or GC-MS analysis to verify acetylacetone production. 
Table 3 Strains and plasmids used in this study

\begin{tabular}{|c|c|c|}
\hline Strains or plasmids & Genotype/description & Source \\
\hline \multicolumn{3}{|l|}{ Strains } \\
\hline E. coli DH5 & $\mathrm{F}^{-}$recA endA1 Ф80dlacZIM15 hsdR17( $\left.r_{K}^{-} m_{K}^{+}\right) \lambda^{-}$ & Invitrogen \\
\hline E. coli BL21 (DE3) & $\mathrm{F}^{-}$ompThsdS $\left(r_{B}^{-} m_{B}^{-}\right)$gal dcm $\lambda(\mathrm{DE} 3)$ & Invitrogen \\
\hline Q2837 & E. coli BL21(DE3) carrying pETDuet-Dke1 and pACYCDuet-MgsA-TpiA & This study \\
\hline Q3028 & E. coli BL21(DE3) carrying pETDuet-Tmo_Dke1 & This study \\
\hline Q3029 & E. coli BL21(DE3) carrying pETDuet-Pxe_Dke1 & This study \\
\hline Q3030 & E. coli BL21(DE3) carrying pETDuet-Dke1 & This study \\
\hline Q3080 & E. coli BL21(DE3) carrying pM1 & This study \\
\hline Q3081 & E. coli BL21(DE3) carrying pM2 & This study \\
\hline Q3082 & E. coli BL21(DE3) carrying pM3 & This study \\
\hline Q3085 & E. coli BL21(DE3) carrying pM6 & This study \\
\hline Q3086 & E. coli BL21(DE3) carrying pM7 & This study \\
\hline Q3148 & E. coli BL21(DE3) carrying pM9 & This study \\
\hline Q3149 & E. coli BL21(DE3) carrying pM10 & This study \\
\hline Q3150 & E.coli BL21(DE3) carrying pM11 & This study \\
\hline Q3151 & E. coli BL21(DE3) carrying pM12 & This study \\
\hline Q3152 & E. coli BL21(DE3) carrying pM13 & This study \\
\hline Q3153 & E. coli BL21(DE3) carrying pM14 & This study \\
\hline Q3154 & E. coli BL21(DE3) carrying pM15 & This study \\
\hline Q3155 & E. coli BL21(DE3) carrying pM16 & This study \\
\hline Q3170 & E. coli BL21(DE3) carrying pM17 & This study \\
\hline \multicolumn{3}{|l|}{ Plasmids } \\
\hline pETDuet-1 & $A m p^{R}$, rep $p_{p B R 322}$, lacl $P_{T 7}$ & Novagen \\
\hline pACYCDuet-1 & $\mathrm{Cm}^{\mathrm{R}}, \mathrm{p} 15 \mathrm{~A}$ origin, lacl $\mathrm{P}_{\mathrm{T}}$ & Novagen \\
\hline pETDuet-Dke1 & pETDuet-1 harboring acetylacetone-cleaving enzyme (Dke1) from A. johnsonii & This study \\
\hline pETDuet-Tmo_Dke1 & pETDuet-1 harboring acetylacetone-cleaving enzyme from T. mobilis & This study \\
\hline pETDuet-Pxe_Dke1 & pETDuet-1 harboring acetylacetone-cleaving enzyme from P.xenovorans & This study \\
\hline pACYCDuet-MgsA-TpiA & $\begin{array}{l}\text { pACYCDuet-1 harboring methylglyoxal synthase (MgsA) and triose-phosphate isomerase } \\
\text { (TpiA) from E. coli }\end{array}$ & This study \\
\hline pM1 & $\operatorname{rep}_{\mathrm{pBR322}} \mathrm{Amp}^{\mathrm{R}}$ lacl $\mathrm{P}_{\mathrm{T} 7} \mathrm{Dke}^{\mathrm{K} 15 \mathrm{Q}}$ & This study \\
\hline $\mathrm{pM} 2$ & $\operatorname{rep}_{\mathrm{pBR322}} \mathrm{Amp}^{\mathrm{R}}$ lacl $\mathrm{P}_{\mathrm{T}} \mathrm{Dke1}^{\mathrm{S} 17 \mathrm{D}}$ & This study \\
\hline $\mathrm{pM} 3$ & $\operatorname{rep}_{\mathrm{pBR322}} \mathrm{Amp}^{\mathrm{R}}$ lacl $\mathrm{P}_{\mathrm{T} 7} \mathrm{Dke1}^{\mathrm{Y} 21 \mathrm{~W}}$ & This study \\
\hline pM6 & $\operatorname{rep}_{\mathrm{pBR} 322} \mathrm{Amp}^{\mathrm{R}} / \mathrm{acl} \mathrm{P}_{\mathrm{T} 7} \mathrm{Dke1}^{\mathrm{L} 103 \mathrm{R}}$ & This study \\
\hline $\mathrm{pM} 7$ & $\operatorname{rep}_{\mathrm{pBR} 322} \mathrm{Amp}^{\mathrm{R}}$ lacl $\mathrm{P}_{\mathrm{T} 7} \mathrm{Dke1}^{\mathrm{G} 105 \mathrm{D}}$ & This study \\
\hline $\mathrm{pM} 9$ & $\operatorname{rep}_{\mathrm{pBR322}} \mathrm{Amp}^{\mathrm{R}}$ lacl $\mathrm{P}_{\mathrm{T} 7} \mathrm{Dke}^{\mathrm{A60D}}$ & This study \\
\hline $\mathrm{pM} 10$ & $\operatorname{rep}_{\mathrm{pBR} 322} \mathrm{Amp}^{\mathrm{R}}$ lacl $\mathrm{P}_{\mathrm{T}} \mathrm{Dke1}^{\mathrm{A} 60 \mathrm{~N}}$ & This study \\
\hline pM11 & $\operatorname{rep}_{\mathrm{pBR} 322} \mathrm{Amp}^{\mathrm{R}}$ lacl $\mathrm{P}_{\mathrm{T} 7} \mathrm{Dke1}^{\mathrm{G} 101 \mathrm{~N}}$ & This study \\
\hline pM12 & $\operatorname{rep}_{\mathrm{pBR322}} \mathrm{Amp}^{\mathrm{R}}$ lacl P $\mathrm{T}_{\mathrm{T}} \mathrm{Dke1}^{\mathrm{G} 101 \mathrm{D}}$ & This study \\
\hline pM13 & $\operatorname{rep}_{\mathrm{pBR} 322} \mathrm{Amp}^{\mathrm{R}}$ lacl $\mathrm{P}_{\mathrm{T} 7} \mathrm{Dke1}^{\mathrm{G} 101 \mathrm{~S}}$ & This study \\
\hline pM14 & $\operatorname{rep}_{\mathrm{pBR322}} \mathrm{Amp}^{\mathrm{R}}$ lacl $\mathrm{P}_{\mathrm{T} 7} \mathrm{Dke1}^{\mathrm{L} 103 \mathrm{C}}$ & This study \\
\hline pM15 & $\operatorname{rep}_{\mathrm{pBR} 322} \mathrm{Amp}^{\mathrm{R}}$ lacl $\mathrm{P}_{\mathrm{T} 7} \mathrm{Dke1}^{\mathrm{L} 103 \mathrm{Q}}$ & This study \\
\hline pM16 & $\operatorname{rep}_{\mathrm{pBR322}} \mathrm{Amp}^{\mathrm{R}}$ lacl $\mathrm{P}_{\mathrm{T} 7} \mathrm{Dke1} 1^{\mathrm{E} 140 \mathrm{~V}}$ & This study \\
\hline pM17 & $\operatorname{rep}_{\mathrm{pBR} 322} \mathrm{Amp}^{\mathrm{R}}$ lacl $\mathrm{P}_{\mathrm{T} 7} \mathrm{Dke1}^{\mathrm{K} 15 \mathrm{Q} / \mathrm{A} 60 \mathrm{D}}$ & This study \\
\hline
\end{tabular}

\section{Shake-flask cultivation}

To evaluate the acetylacetone production using different engineered strains, shake-flask cultivations were carried out with $50 \mathrm{~mL}$ of liquid LB medium containing $20 \mathrm{~g} / \mathrm{L}$ glucose in $250-\mathrm{mL}$ non-baffled flasks or serum bottles with appropriate antibiotics. When necessary, ampicillin and chloramphenicol were added at a final concentration of $100 \mu \mathrm{g} / \mathrm{mL}$ and $50 \mu \mathrm{g} / \mathrm{mL}$, respectively. The strains were inoculated to the medium and incubated in an orbital shaker incubator at $37^{\circ} \mathrm{C}$ and $180 \mathrm{rpm} .0 .2 \mathrm{mM}$ 
IPTG was added into the medium to induce the recombinant protein expression when the cells reached at about 0.6-0.8 $\mathrm{OD}_{600}$. Nitrogen protection was introduced to create an anaerobic environment in the serum bottle. After induction, the temperature was set at $30^{\circ} \mathrm{C}$ for further $24 \mathrm{~h}$ cultivation. All shake-flask experiments were performed in triplicate.

\section{Fed-batch fermentation}

For large-scale production, fed-batch fermentation was carried out in a Biostat B plus MO5L bioreactor (Sartorius Stedim Biotech $\mathrm{GmbH}$, Germany) containing $2 \mathrm{~L}$ growth medium $(20 \mathrm{~g} / \mathrm{L}$ tryptone, $10 \mathrm{~g} / \mathrm{L}$ yeast extract, $20 \mathrm{~g} / \mathrm{L} \mathrm{NaCl}, 3 \mathrm{~g} / \mathrm{L} \mathrm{KH}_{2} \mathrm{PO}_{4}, 0.26 \mathrm{~g} / \mathrm{L} \mathrm{MgSO}_{4}, 1.0 \mathrm{~g} / \mathrm{L}$ $\mathrm{NH}_{4} \mathrm{Cl}, 15.2 \mathrm{~g} / \mathrm{L} \mathrm{Na} \mathrm{HPO}_{4}, 20 \mathrm{~g} / \mathrm{L}$ glucose and $2 \mathrm{~mL}$ of trace element solution). The trace element solution contained (per liter) $3.7 \mathrm{~g}\left(\mathrm{NH}_{4}\right)_{6} \mathrm{Mo}_{7} \mathrm{O}_{24} \cdot 4 \mathrm{H}_{2} \mathrm{O}, 2.47 \mathrm{~g}$ $\mathrm{H}_{3} \mathrm{BO}_{3}, 1.58 \mathrm{~g} \mathrm{MnCl}_{2} \cdot 4 \mathrm{H}_{2} \mathrm{O}, 0.29 \mathrm{~g} \mathrm{ZnSO}_{4} \cdot 7 \mathrm{H}_{2} \mathrm{O}$, and $0.25 \mathrm{~g} \mathrm{CuSO}_{4} \cdot 5 \mathrm{H}_{2} \mathrm{O}$. Two hundred milliliters of overnight seed culture was inoculated into the bioreactor to start the fermentation at $37^{\circ} \mathrm{C}$. During the fermentation, sterilized air was supplied at $1 \mathrm{vvm}$ and ammonia was added automatically to control the $\mathrm{pH} 7$. The agitation speed was set at $400 \mathrm{rpm}$ and then associated with the dissolved oxygen to maintain the concentration at $20 \%$ saturation. Fed-batch mode was commenced by feeding $60 \%$ glucose when the dissolved oxygen increased. When the cell density reached to an $\mathrm{OD}_{600}$ of 30 , the recombinant proteins were induced by $0.2 \mathrm{mM}$ IPTG along with $0.5 \mathrm{mM} \mathrm{FeSO} \cdot 7 \mathrm{H}_{2} \mathrm{O}$ added, and nitrogen was used for anaerobic conditioning after induction. The temperature was adjusted to $30{ }^{\circ} \mathrm{C}$ for further cultivation. The agitation speed was kept at a constant rate of $200 \mathrm{rpm}$ during anaerobic fermentation. More details of the fed-batch fermentation are presented in Additional file 1: Fig. S5 and Additional file 2: Fed-batch fermentation. $5 \mathrm{~mL}$ of the fermentation broth was withdrawn periodically to determine the cell density, residual glucose and product titer. The fed-batch fermentation was performed in triplicate.

\section{Molecular docking}

Molecular docking of acetylacetone with Dke1 was carried out with AutoDock 4.2.6 program. The initial structure was prepared using AutoDockTools 1.5.6 [32], preserving the original charge of the protein and generating a pdbqt file for docking. The 3D structure of the acetylacetone was downloaded from the PubChem database. MOPAC program was then used to optimize the structure and calculate the PM3 atomic charge. The structure of acetylacetone was also prepared by AutoDock Tools 1.5.6, and the corresponding pdbqt file was generated for docking. The active site of Dke1 was chosen as the binding pocket for docking. The number of grid points in the $X Y Z$ of grid box was set to $40 \times 40 \times 40$, the grid spacing was $0.375 \AA$, the number of Genetic Algorithm (GA) run was set to 100 , and the rest parameters were set to default. Finally, the structure with the lowest docking energy was carried out with energy minimization. The optimization process is carried out in two steps: first, the steepest descent method optimization of 2000 steps, then the structure was further optimized by the 2000 steps with conjugate gradient method.

\section{Analytic methods}

The OD at $600 \mathrm{~nm}$ was routinely used to monitor cell growth via ultraviolet spectrophotometer (Varian Cary $50 \mathrm{UV}-\mathrm{Vis}$, US), and one unit of $\mathrm{OD}_{600}$ was equivalent to $0.43 \mathrm{~g} \mathrm{DCW} / \mathrm{L}$ [33]. The residual glucose was determined by an SBA-40D biosensor analyzer (Institute of Biology, Shandong Academy of sciences, China). The culture samples were centrifuged at $10,000 \times g$ for $10 \mathrm{~min}$; the supernatants were filtered through a $0.2-\mu \mathrm{M}$ Tuffryn membrane (China) and used for HPLC analysis (Waters 1525, $300 \mathrm{~mm} \times 7.8 \mathrm{~mm}$ Aminex HPX-87H, UV-Vis detector at $280 \mathrm{~nm}$, for more detailed information see Additional file 1: Fig. S6 and Additional file 2: Standard curve establishment and Table S3). To further confirm acetylacetone production in our cultures, the same sample was analyzed by GC-MS after HPLC determination. The GC-MS analysis was performed with an Agilent GC quadrupole instrument. The analysis conditions were as follows: a 30-m HP-5 column (internal diameter $0.25 \mathrm{~mm}$, film thickness $0.25 \mu \mathrm{m}$ ), the column temperature program was composed of an initial hold at $50^{\circ} \mathrm{C}$ for 5 min, ramping at $15{ }^{\circ} \mathrm{C}$ per min to $240{ }^{\circ} \mathrm{C}$ and holding for $5 \mathrm{~min}$. The injector and transfer line temperature were 240 and $250{ }^{\circ} \mathrm{C}$, respectively. The mass spectrometry full scan was from 30 to 400 , the ion source and quadrupole temperature were 230 and $150{ }^{\circ} \mathrm{C}$, respectively.

\section{Supplementary information}

Supplementary information accompanies this paper at https://doi. org/10.1186/s13068-020-01725-9.

Additional file 1. Additional figures.

Additional file 2. Additional tables.

\section{Abbreviations}

Dke1: Acetylacetone-cleaving enzyme; TpiA: Triose-phosphate isomerase; MgsA: Methylglyoxal synthase; E. coli: Escherichia coli; A. johnsonii: Acinetobacter johnsonii; GC-MS: Gas chromatography-mass spectrometer; HPLC: Highperformance liquid chromatography; $\mathrm{OD}_{600}$ : Optical density at wavelength 600 nm; DTT: Dithiothreitol; IPTG: Isopropyl- $\beta$-D-thiogalactoside; DCW: Dry cell weight.

\section{Acknowledgements}

We thank Miss Yingxin Fu (QIBEBT, CAS) for her work on the additional acetylacetone tolerance experiment, especially she has overcome many difficulties that is being caused by the COVID-19 pandemic. 


\section{Authors' contributions}

$X F$ and $G Z$ designed the study. $Y Z, W G, J W$, and $X L$ carried out the experiments. $G Z, X F, Y D, X M$, and $Y Z$ contributed to discuss and analyze the data. $X F$, $G Z, Y Z$, and $M X$ wrote the manuscript. All authors read and approved the final manuscript.

\section{Funding}

This work was supported by the National Defense Science and Technology Innovation Zone Foundation of China, National Natural Science Foundation of China (31722001, 31670089, and 31800081), Taishan Scholars Program of Shandong Province (ts201712076), Natural Science Foundation of Shandong (JQ201707 and ZR2019QB015), and the Youth Innovation Promotion Association at the Chinese Academy of Sciences.

\section{Availability of data and materials}

We provide all the necessary data for the publication of this article. All additional data are present in the article and the additional material documents.

\section{Ethics approval and consent to participate}

Not applicable.

\section{Consent for publication}

Not applicable.

\section{Competing interests}

The authors declare that they have no competing interests.

\section{Author details}

${ }^{1}$ CAS Key Laboratory of Biobased Materials, Qingdao Institute of Bioenergy and Bioprocess Technology, Chinese Academy of Sciences, Qingdao 266101, China. ${ }^{2}$ University of Chinese Academy of Sciences, Beijing 100049, China. ${ }^{3}$ Institute of Oceanology, Chinese Academy of Sciences, Qingdao 266071, China. ${ }^{4}$ State Key Laboratory of Microbial Technology, Shandong University, Qingdao 266237, China.

\section{Received: 12 March 2020 Accepted: 7 May 2020}

Published online: 15 May 2020

\section{References}

1. Chia M, SchwartzTJ, Shanks BH, Dumesic JA. Triacetic acid lactone as a potential biorenewable platform chemical. Green Chem. 2012;14:1850.

2. Siegel H, Eggersdorfer M. Ketones. In: Ullmann's encyclopedia of industrial chemistry. Weinheim: Wiley-VCH; 2002.

3. Hwang YL, Bedard TC. Ketones. In: Kirk-Othmer encyclopedia of chemical technology. Hoboken: Wiley; 2001.

4. Jiang XL, Zhang HB, Yang JM, Zheng YN, Feng DX, Liu W, Xu X, Cao YJ, Zou HB, Zhang RB, Cheng T, Jiao FJ, Xian M. Biodegradation-inspired bioproduc tion of methylacetoin and 2-methyl-2,3-butanediol. Sci Rep. 2013;3:2445

5. Jang YS, Kim B, Shin JH, Choi YJ, Choi S, Song CW, Lee J, Park HG, Lee SY. Bio-based production of C2-C6 platform chemicals. Biotechnol Bioeng. 2012;109:2437-59.

6. Ro DK, Paradise EM, Ouellet M, Fisher KJ, Newman KL, Ndungu JM, Ho KA, Eachus RA, Ham TS, Kirby J, Chang MCY, Withers ST, Shiba Y, Sarpong R, Keasling JD. Production of the antimalarial drug precursor artemisinic acid in engineered yeast. Nature. 2006:440:940-3.

7. Chen GQ, Hajnal I, Wu H, Lv L, Ye J. Engineering biosynthesis mechanisms for diversifying polyhydroxyalkanoates. Trends Biotechnol. 2015;33:565-74.

8. Straganz GD, Brecker L, Weber HJ, Steiner W, Ribbons DW. A novel $\beta$-diketone-cleaving enzyme from Acinetobacter johnsonii: acetylacetone 2,3-oxygenase. Biochem Biophys Res Commun. 2002;297:232-6.

9. Straganz GD, Glieder A, Brecker L, Ribbons DW, Steiner W. Acetylacetonecleaving enzyme Dke1: a novel C-C-bond-cleaving enzyme from Acinetobacter johnsonii. Biochem J. 2003;369:573-81.

10. Yim H, Haselbeck R, Niu W, Pujol-Baxley C, Burgard A, Boldt J, Khandurina J, Trawick JD, Osterhout RE, Stephen R, Estadilla J, Teisan S, Schreyer HB, Andrae S, Yang TH, Lee SY, Burk MJ, Dien SV. Metabolic engineering of Escherichia coli for direct production of 1,4-butanediol. Nat Chem Biol. 2011:7:445-52.
11. Clomburg JM, Vick JE, Blankschien MD, Rodriguez-Moya M, Gonzalez R. A synthetic biology approach to engineer a functional reversal of the B-oxidation cycle. ACS Synth Biol. 2012;1:541-54.

12. Clomburg JM, Blankschien MD, Vick JE, Chou A, Kim S, Gonzalez R. Integrated engineering of $\beta$-oxidation reversal and $\omega$-oxidation pathways for the synthesis of medium chain $\omega$-functionalized carboxylic acids. Metab Eng. 2015;28:202-12.

13. Dellomonaco C, Clomburg JM, Miller EN, Gonzalez R. Engineered reversal of the $\beta$-oxidation cycle for the synthesis of fuels and chemicals. Nature. 2011;476:355-9.

14. Hopper DJ, Cooper RA. The regulation of Escherichia coli methylglyoxal synthase; a new control site in glycolysis? FEBS Lett. 1971;13:213-6.

15. Zhang YHP, Sun J, Zhong JJ. Biofuel production by in vitro synthetic enzymatic pathway biotransformation. Curr Opin Biotechnol. 2010;21:663-9.

16. Feng XJ, Gao WJ, Zhou YF, Zhao ZQ, Liu XT, Han XJ, Xian M, Zhao G. Coupled biosynthesis and esterification of 1,2,4-butanetriol to simplify its separation from fermentation broth. Eng Life Sci. 2019;19:444-51.

17. Ferguson GP, Tötemeyer S, MacLean MJ, Booth IR. Methylglyoxal production in bacteria: suicide or survival? Arch Microbiol. 1998;170:209-19.

18. Luo X, Wang YJ, Shen W, Zheng YG. Activity improvement of a Kluyveromyces lactis aldo-keto reductase KIAKR via rational design. J Biotechnol. 2016;224:20-6.

19. Zheng GW, Xu JH. New -opportunities for biocatalysis: driving the synthesis of chiral chemicals. Curr Opin Biotechnol. 2011;22:784-92.

20. Lutz S. Beyond directed evolution - semi-rational protein engineering and design. Curr Opin Biotechnol. 2010;21:734-43.

21. Straganz GD, Egger S, Aquino G, Auria SD, Nidetzky B. Exploring the cupintype metal-coordinating signature of acetylacetone dioxygenase Dke1 with site-directed mutagenesis: catalytic reaction profile and $\mathrm{Fe}^{2+}$ binding stability of Glu-69 $\rightarrow$ Gln mutant. J Mol Catal B Enzyme. 2006:39:171-8.

22. Brkić H, Buongiorno D, Ramek M, Straganz G, Tomić S. Dke1—structure, dynamics, and function: a theoretical and experimental study elucidating the role of the binding site shape and the hydrogen-bonding network in catalysis. J Biol Inorg Chem. 2012;17:801-15.

23. Xu W, Yao J, Liu LJ, Ma X, Li W, Sun XJ, Wang Y. Improving squalene production by enhancing the NADPH/NADP ${ }^{+}$ratio, modifying the isoprenoidfeeding module and blocking the menaquinone pathway in Escherichia coli. Biotechnol Biofuels. 2019:12:68.

24. Wu G, Yan Q, Jones JA, Tang YJ, Fong SS, Koffas MAG. Metabolic burden: cornerstones in synthetic biology and metabolic engineering applications. Trends Biotechnol. 2016;34(8):652-64.

25. Ajikumar PK, Xiao WH, Tyo KEJ, Wang Y, Simeon F, Leonard E, Mucha O, Phon HT, Pfeifer B, Stephanopoulos G. Isoprenoid pathway optimization for Taxol precursor overproduction in Escherichia coli. Science. 2010;330(6000):70-4.

26. Ballantyne B. 2, 4-pentanedione. J Appl Toxicol. 2001;21:165-71.

27. Thurston RV, Gilfoil TA, Meyn EL, Zajdel RK, Aoki TI, Veith GD. Comparative toxicity of ten organic chemicals to ten common aquatic species. Water Res. 1985;19:1145-55.

28. Bringmann G, Kühn R. Comparison of the toxicity thresholds of water pollutants to bacteria, algae, and protozoa in the cell multiplication inhibition test. Water Res. 1980;14:231-41.

29. Mo WJ, Wang MZ, Zhan RR, Yu Y, He YG, Lu H. Kluyveromyces marxianus developing ethanol tolerance during adaptive evolution with significant improvements of multiple pathways. Biotechnol Biofuels. 2019;12:63.

30. Kang YS, Weber KD, Qiu Y, Kiley PJ, Blattner FR. Genome-wide expression analysis indicates that FNR of Escherichia coli $\mathrm{K}-12$ regulates a large number of genes of unknown function. J Bacteriol. 2005;187(3):1135-60.

31. Tong WH, Xu Y, Xian M, Niu W, Guo JT, Liu HZ, Zhao G. Biosynthetic pathway for acrylic acid from glycerol in recombinant Escherichia coli. Appl Microbiol Biotechnol. 2016:100:4901-7.

32. Sanner MF. Python: a programming language for software integration and development. J Mol Graph Model. 1999:17:57-61.

33. Yee L, Blanch HW. Recombinant trypsin production in high cell density fedbatch cultures in Escherichia coli. Biotechnol Bioeng. 1993:41:781-90.

\section{Publisher's Note}

Springer Nature remains neutral with regard to jurisdictional claims in published maps and institutional affiliations. 